\title{
An institutional approach for developing South African inland freshwater fisheries for improved food security and rural livelihoods
}

\author{
Mafaniso M Hara ${ }^{1 *}$ and Gerhard R Backeberg ${ }^{2}$ \\ 'Institute for Poverty, Land and Agrarian Studies (PLAAS), University of the Western Cape, P/Bag X17, Bellville 7535, South Africa \\ ${ }^{2}$ Water Utilisation in Agriculture, Water Research Commission (WRC), Private Bag X03, 0031 Gezina, Pretoria, South Africa
}

\begin{abstract}
South Africa has over 4700 storage dams, about 700 of which are owned and controlled by Government. Public dams were primarily constructed for domestic, irrigation and industrial water supply. Over time secondary uses for recreation and tourism have been established. Many of the public dams have been stocked with indigenous and alien fish species, predominantly for recreational angling. Given widespread rural unemployment, poverty and undernourishment, the development of inland fisheries on public dams and natural water bodies has much potential for improving rural livelihoods and food security. There is also potential for inclusion of communities in other value chains linked to economic activities around public dams such as recreational fishing and tourism.

The public dams and natural water bodies fall under various implicit institutional arrangements depending on primary and secondary activities on a given water body. These determine the existing formal and informal power dynamics and related decision-making arrangements and controls under current use-right practices. This paper analyses the existing property rights that determine access, co-management options and governance arrangements necessary to promote sustainable development of inland fisheries in South Africa. Attention needs to be given to the various ways of explicit definition and enforcement of property and access rights if communities are to realise the potential benefits from use of public dams for fisheries and other economic activities. Achieving this will require a developmental approach based on principles of inclusive, representative, equitable, accountable and effective governance. Leadership by the line agency Department of Agriculture, Forestry and Fisheries - will be critical for success of such an initiative.
\end{abstract}

Keywords: Storage dams, freshwater fisheries, poverty and livelihoods, property and access rights, governance, developmental approach, South Africa

\section{INTRODUCTION}

Small-scale fisheries play a significant role in food security, poverty reduction and income generation (Jentoft and Eide, 2011; Béné et al., 2010; Béné et al., 2007; Heck et al., 2007; FAO, 2003). The importance of small-scale fisheries is further underlined by the fact that this sector employs over $95 \%$ of all men and women engaged in fisheries worldwide and that of these more than $90 \%$ are to be found in developing countries (FAO, 2009). In Africa, it is estimated that the fishing sector provides income for over 10 million people and contributes to the food security of over 200 million people (FAO, 2005). Inland fisheries are a vital part of fisheries in Africa, especially Sub-Saharan Africa where the large lakes (Victoria, Malawi/Niasa, Kariba, Banguelu, etc) occur. In South Africa, however, fisheries have historically been dominated by the commercial marine sector, even though the country has hundreds of inland storage dams and impoundments. Despite their potential, these inland water resources remain largely under or unutilised for provision of fish protein and nutrition security, income and employment for the rural poor living in the vicinity of these resources. One of the key reasons why this potential has not so far been realised is the lack of Government policy on inland fisheries and capacity required to develop and support the sector (McCafferty et al.,

To whom all correspondence should be addressed.

Iili +27 21959 3772; fax: +27 21959 3732;

e-mail: mhara@plaas.org.za

Received 1 May 2013; accepted in revised form 3 March 2014.
2012; Hara and Ngwexana, 2011). An important consequence of this lack of policy is the unclear definition, specification and insecure recognition of property rights to these resources and also the lack of viable management approaches for the sector.

\section{Research on freshwater inland fisheries in South Africa}

Given the existing knowledge gaps, a baseline and scoping study was initiated by the South African Water Research Commission (WRC) on the development and sustainable use of storage dams for freshwater inland fisheries and their contribution to rural livelihoods (WRC, 2011). The conceptual framework for research (Fig. 1) on the sustainable utilisation of inland fisheries proposes a holistic enhancement of all the key sub-systems of the sector: better knowledge and understanding of the resource base consisting of indigenous and alien fish stocks in small and large storage dams as influenced by the quantity and quality of water; access to these resources through various types of property rights that determine the relations of people to resources; and relevant legislation with regulations through which control is exercised over resources and people. This in turn will be influenced by organisation for management based on peoples' knowledge (indigenous, local and scientific), and type of fishing (recreation, subsistence or commercial) within a sustainable livelihoods framework. All of the above will need to be buttressed by just, participatory, transparent, accountable and effective governance. The framework (Fig. 1) was developed in the early stages of this WRC-funded research project and later presented during a consultative workshop (Backeberg, 2012). The purpose was to emphasize the 
INLAND FRESHWATER FISHERIES: CONCEPTUAL FRAMEWORK

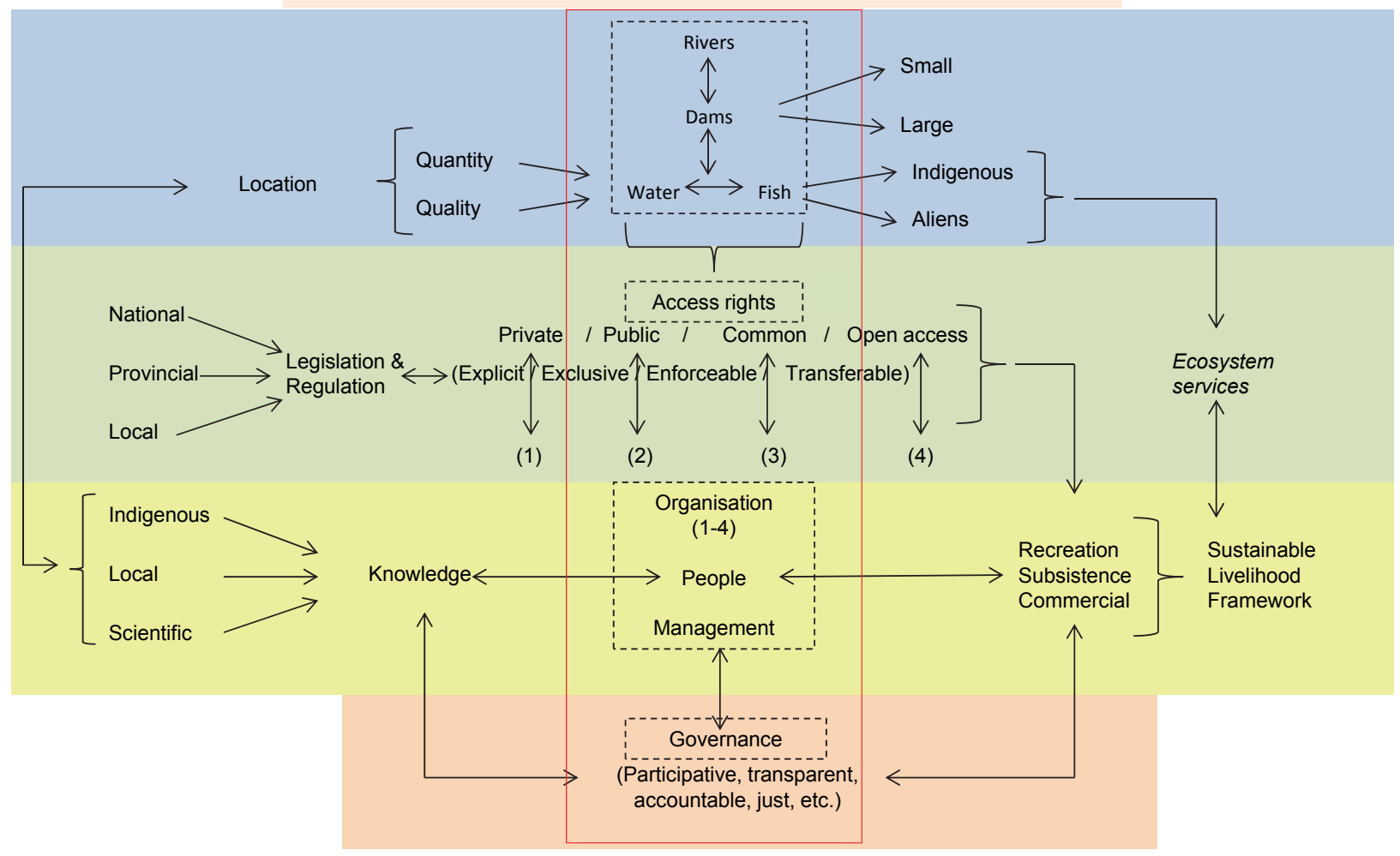

Figure 1

Governance and institutional framework for sustainable development of inland fisheries in South Africa (Source: Backeberg, 2012)

interrelatedness of all sub-systems and components that form the system for freshwater inland fisheries. In turn, the intention was to focus attention on the contributions to be made by different natural and social scientists who are members of the multi-disciplinary research team. With the discussion below, primary attention is given to various property rights and institutional arrangements that enable access to water and fish resources in public storage dams, as well as the way people organise themselves through co-management to make productive use of these resources (in particular those sub-systems highlighted in the rectangular frame in the centre of Fig. 1). This paper therefore proposes an institutional approach for productive exploitation of freshwater inland fisheries in South Africa. It examines the existing property rights and management options in order to make recommendations for secure access rights to inland fisheries for rural communities, and improved governance for sustainable development of the sector. Other components of the project resource base (Weyl, 2012) and indigenous knowledge and characterisation of fishing practices (Tapela et al., 2011) were investigated by other members of the team.

\section{Property rights and property right regimes}

Four different ideal analytic types of property right regimes are distinguished, namely state or public property, common or communal property, private or freehold property, and nonproperty or open access (Berkes et al., 1989; Bromley, 1989). A particular resource can be held under more than one property rights regime (Ostrom, 1986; Bromley, 1989). Property right regimes refer to institutional arrangements that define the conditions for access to, and control over resources (Bromley,
1989, 1991; Bromley and Cernea, 1989; Ostrom 1986, 1990; Young, 1989). Property right regimes define a combination of ownership, locus of control and rights (of the rights holders) and obligations (of the non-rights holders) regarding a specific resource. Property right regimes function in providing incentives for beneficial use; determining relationships between different users with respect to the resource; and establishing institutional mechanisms for responding to changing environmental conditions. The role of property right regimes and the way these could influence management and governance will be central in restructuring of rights in inland fisheries of South Africa.

Property rights are a key element in the description and analysis of use of particular common pool resources. They assign benefit streams derived from the utilisation of a resource (Bromley, 1989). Property rights are defined by a number of key characteristics such as: exclusivity, transferability, inheritability, alienability and enforcement mechanisms (Alchian and Demsetz 1973; Schlager and Ostrom, 1992; World Bank, 2004). They define the uses that are legitimately viewed as being enforceable and who has these rights. It is important that property rights be consistent with social goals of equity, efficiency and sustainability. Thus property rights give entitlements regarding resource use and rules under which those entitlements are exercised. The necessary conditions of explicit, exclusive, enforceable and transferable entitlements have been shown to be essential for communal land to enable productive individual use for rain-fed crop production (Backeberg, 2010; Manona and Baiphethi, 2008). Comparable entitlements must be systematically designed for common pool resources in storage dams to ensure sustainable harvesting of fish stocks. 


\section{Property rights as 'bundles of rights'}

It has been emphasised that property rights should be considered as bundles of rights (Schlager and Ostrom, 1992; Ciriacy-Wantrup and Bishop, 1975). In this context, 5 rights of operational property systems have been defined from empirical studies, namely: the right to access, the right to withdraw, the right to manage, the right to exclude and the right to alienate (Ostrom, 2008; Schlager and Ostrom, 1992). The different ways in which these bundles can be combined by the agents or holders of entitlements can be related to rights and obligations that agents hold with regard to the operational settings concerning the resource. Five user-resource relational positions can be defined in relation to the operational property systems defined above. These are Viewer, Authorised User, Claimant, Proprietor and Owner (Schlager and Ostrom, 1992). The possible bundles of rights that a right holder can hold and combine and the associated position this entails for the right holder towards the resource are summarised in Table 1.

Schlager (1994) and Schlager and Ostrom (1992) found that possessing claimant's rights (access, withdrawal and management) did positively affect the capabilities of the claimants to self-organise. Having the authority to exclude others (proprietary rights) gave them even more capabilities to ensure that others did not invade their resource and gave the proprietors confidence to invest in regulating use and in other improvements in 'their' resource. Evidence indicates that the right to alienate a resource is not the key and defining right for common property systems that have survived for a long time (Schlager and Ostrom, 1992; Netting 1981; McKean, 1992) and for those agents who have been able to design and maintain long-enduring common property rights systems (Ostrom, 1990; Schlager, 1994; Tang, 1994).

Empirically therefore, many users of common pool resources have secure property rights bundles even though these may not include the right of alienation.

In the context of South African inland fisheries largely being based on use of public storage dams, access rights for fishing will be secondary to and also overlap with the primary use of dams as sources of water for domestic, industrial and irrigation purposes. The type (whether group or individual, free or permit based) and form (whether subsistence, commercial or recreation) of fishing rights will depend on factors such as geographic location of the given water body in relation to potential fishing communities. Important will be productivity of the dam and the species stocked in the dam (Weyl et al., 2007; McCafferty et al. 2012). Also key will be the viable organisational structures necessary for ensuring sustainable utilisation of inland fisheries, given that currently ownership and control of dams and responsibility for management of the various resources that occur in dams, is shared among a number of government departments and user group organisations.

\section{Dams for potential inland fisheries in South Africa}

This research project (WRC, 2011) considered the use of public dams for the development of inland fisheries for increased food security in rural communities that have or could have access to these dams. The Department of Water Affairs (DWA) list of registered dams of October 2010 (DWA, 2010) gives a combined total of 4703 dams in South Africa for private and public dams. Of these, 704 (15\%) were listed as public dams (controlled by DWA, municipalities, Department of Agriculture Forestry and Fisheries, Department of Correctional Services, etc.) of varying sizes with 132 (18.8\%) being large (with wall over $30 \mathrm{~m}$ ), 273 (38.8\%) being medium size (with a wall of 12 to $30 \mathrm{~m}$ ) and 293 (41.8\%) being small (with a wall less than $12 \mathrm{~m}$ ) (Table 2).

The total surface area for all dams (private and public) in South Africa was about 1500422.45 hectares (DWA, 2010). Of this 791643.07 hectares (53\%) were public dams. These are spread across all 9 provinces including those that exhibit the most rural-based and impoverished populations in the country, such as Eastern Cape, KwaZulu-Natal, Limpopo, Mpumalanga and the North West (see Table 2).

\section{METHODS}

Two approaches were used for the study: a sample survey of public dams around issues of property rights, related access rights and management regimes; and an analysis of legislation important for inland fisheries.

\begin{tabular}{|l|c|c|c|c|c|}
\hline \multicolumn{7}{|c|}{$\begin{array}{c}\text { TABLE 2 } \\
\text { Total number of public dams in South Africa according to size (Hara and } \\
\text { Ngwexana, 2011) }\end{array}$} \\
\hline \multirow{2}{*}{ Province } & \multicolumn{5}{|c|}{ Size of dam } \\
\cline { 2 - 6 } & Large & Medium & Small & Non-categorised & \\
\hline Eastern Cape & 31 & 52 & 41 & 1 & 125 \\
\hline Free State & 8 & 33 & 36 & & 77 \\
\hline Gauteng & 12 & 17 & 59 & & 88 \\
\hline KwaZulu-Natal & 12 & 24 & 26 & & 62 \\
\hline Limpopo & 14 & 26 & 12 & & 52 \\
\hline Mpumalanga & 16 & 35 & 19 & 2 & 72 \\
\hline Northern Cape & 2 & 5 & 9 & 2 & 18 \\
\hline North West & 7 & 21 & 29 & & 57 \\
\hline Western cape & 28 & 59 & 53 & 1 & 141 \\
\hline Total & $\mathbf{1 3 2}$ & $\mathbf{2 7 3}$ & $\mathbf{2 9 3}$ & $\mathbf{6}$ & $\mathbf{7 0 4}$ \\
\hline
\end{tabular}

\section{TABLE 1}

Bundles of rights and associated operational positions towards resource (adapted from Ostrom, 2008; Schlager and Ostrom, 1992)

\begin{tabular}{|l|c|c|c|c|c|}
\hline \multirow{2}{*}{ Type of right } & \multicolumn{5}{|c|}{ Associated position } \\
\cline { 2 - 6 } & Viewer & Authorised user & Claimant & Proprietor & Owner \\
\hline Access & $\mathrm{X}$ & $\mathrm{X}$ & $\mathrm{X}$ & $\mathrm{X}$ & $\mathrm{X}$ \\
\hline Withdrawal & & $\mathrm{X}$ & $\mathrm{X}$ & $\mathrm{X}$ & $\mathrm{X}$ \\
\hline Management & & & $\mathrm{X}$ & $\mathrm{X}$ & $\mathrm{X}$ \\
\hline Exclusion & & & & $\mathrm{X}$ & $\mathrm{X}$ \\
\hline Alienation & & & & & $\mathrm{X}$ \\
\hline
\end{tabular}




\section{Sample survey of public dams}

Given the large number of public dams, purposive sampling was used for case study dam selection. The selected public dams were, as much as possible, selected for the variation they could provide with regard to property and access rights and management arrangements. The dams that were sampled are listed in Table 3.

\begin{tabular}{|c|c|c|}
\hline \multicolumn{3}{|c|}{$\begin{array}{c}\text { TABLE } 3 \\
\text { List of dams sample surveyed }\end{array}$} \\
\hline & Dam or water body & Province \\
\hline 1 & Driekoppies & Mpumalanga \\
\hline 2 & Lake Fundudzi & \multirow[t]{3}{*}{ Limpopo } \\
\hline 3 & Nandoni & \\
\hline 4 & Makuleke & \\
\hline 5 & uPhongolo (Lake Jozini) & \begin{tabular}{|l|} 
KwaZulu-Natal \\
\end{tabular} \\
\hline 6 & Voëlvlei & \multirow[t]{3}{*}{ Western Province } \\
\hline 7 & Clanwilliam & \\
\hline 8 & Theewaterskloof & \\
\hline 9 & Bloemhof & Free State \\
\hline
\end{tabular}

The following information was gathered on each of the dams: type of dam/water body; legal custodian; property rights regime under which the dam/water body exists; list of all the users of the dam/water body; management agency for the dam/ water body; and institutional arrangements for management. A list of users was then extracted and for each user the following information was gathered: type of uses each user was making of the dam/water body; type of rights they held; type of permit systems authorising use; and the management regime to which the user was subject to. Particular emphasis was put on detailing aspects that are key for analysing property right regimes, property rights, access rights and institutional arrangements for management. The results of this survey and analysis are given in the Appendix (Table A1).

A total of 33 individuals and organisations were interviewed. These were in the categories of: government officials (for example from the Department of Water Affairs (DWA) and Department of Agriculture, Forestry and Fisheries (DAFF)), provincial environmental scientists, angling club representatives, guest lodge owners and other stakeholders. Apart from Hara and Ngwexana (2011), other deliverables (for example Tapela et al., 2011; and Weyl, 2012) for the broader WRC-funded project also provided useful information for the analysis.

\section{Policy and legislation for inland fisheries}

An analysis of the relevant sections of both national and provincial legislation and policies for inland fisheries, for example the National Water Act (NWA) (No. 36 of 1998), National Environmental Management Act (NEMA) (No. 107 of 1998) and the National Environmental Management: Biodiversity Act (NEMBA) (No. 10 of 2004) and the Traditional Leadership and Governance Framework Amendment Act (TLGF) (No. 41 of 2003) was undertaken. A review of DAFF's development policy and strategy (DAFF, 2010), in terms of how this could facilitate inland fisheries use, was also undertaken.

The theoretical framework provided in Fig. 1, the information from the sample surveys of public dams and the analysis of legislation and policies (Hara and Ngwexana, 2011) were used to provide a diagnostic analysis of, firstly, existing access rights, use rights, techniques, practices and management approaches on public dams, and, secondly, the policies as well as legal instruments being applied or that could be applied for inland fisheries.

\section{RESULTS AND DISCUSSION}

\section{Property and management rights}

The dams and water bodies that are relevant for development of inland fisheries are those owned and controlled by Government. These formally fall under the 'state property regime' (see Fig. 1). It is not envisaged that dams on private land (even though all water belongs to the State under the NWA) could be used to develop inland fisheries that could benefit rural communities. This analysis therefore concerns the existing property rights, access rights and management arrangements on public dams and natural water bodies.

\section{Ownership (custodial) rights}

According to the White Paper on a National Water Policy for South Africa, all water (surface and underground) is a national asset legally held under the stewardship and custodianship of the state on behalf of its citizens (Principles 12 and 13; DWAF, 1997).

Access to water is formally governed by two pieces of legislation namely, the National Water Act (No. 36 of 1998) and the Water Services Act (No. 108 of 1997). While the latter governs domestic water supply services and delegates responsibilities for such services to water services authorities such as municipalities, water utility parastatals and private firms, the former governs authorisations for various uses of water especially on or from public dams. The White Paper on a National Water Policy groups priority water allocation rights into that required for 'basic human use' (Principle 8) and 'ecological needs' (referred to as 'the ecological Reserve') (Principle 10). All other uses are regulated through 'registration' and various types of 'authorisations' (Principle 3).

Under the NWA, there are four types of water use authorisations, namely: Schedule 1; General Authorisations; Existing Lawful Uses; and Water Use Licences. Schedule 1 refers to permissible water uses that do not require a licence and do not have to be registered. This relates to uses that are deemed as being of small quantities that have little impact on the water resource and therefore pose minimal risk. General Authorisations refer to permissions that allow slightly larger volumes of water use from less stressed sources, such as rivers and aquifers, groundwater sources, as well as storage of a limited quantity of water in a dam. This authorisation type allows people to use water without a licence provided that the water use is within the conditions stipulated in the General Authorisation category. Where a user had been using water prior to the NWA, provision was made for 'continuation of existing lawful use'. In this context, such a user is merely required to register that use and continue using water without having to apply for a licence. This provision was supposed to be a transitional measure intended to allow existing lawful water users to continue using water under the same conditions, until water use is formally licensed. Water licences give new water users formal authorisation to use water, and specify the conditions under which the water can be used. Licences are issued by 'responsible authorities', namely, the Department of Water 
Affairs (DWA) or, in future, catchment management agencies (CMAs).

As legal custodians of public dams on behalf of South African citizens, the concerned departments (whether DWA, DAFF, municipalities, etc.) have all possible rights including the right of alienation (in practice, mostly lease - Principle 3 in the White Paper on a National Water Policy; DWAF, 1997). For the concerned departments that have custody of the dams, most important is the ownership (or custodial) right, which gives them the authority to determine who will be allowed access, withdrawal rights, management rights and who will be excluded. For example, the DWA and DAFF give authorisations for bulk extraction of water for domestic or irrigation purposes to municipalities and farmers, respectively. They also give authorisations for infrastructure development such as buildings by clubs, camping sites, lodges, etc. They also issue authorisations for use of dams for water sports such as recreational fishing, tourist passenger boats, etc. Where vessels are being used, a vessel safety certificate (seaworthiness) and use of a qualified vessel operator (with a skipper's licence), which are issued by South African Maritime Safety Authority (SAMSA) are part of the conditions. Of note is that the NWA does not specifically mention fisheries as a resource in dams even though clearly fishing is one of the benefits that recreational and subsistence fishers derive from these dams (Tapela et al., 2011; Weyl et al., 2007; McCafferty et al., 2012).

\section{Management rights and responsibilities}

While the custodial departments for dams retain the authority to give authorisations for extraction of water, recreational uses of dams, and building on dam frontage land, legislation, historically and currently, gives the authority to regulate the use of living organisms in dams (the so called 'management of biodiversity') to provincial departments or boards of the environment (formerly departments of nature conservation). In this context, these departments have the authority to determine access, withdrawal (consumptive), and exclusion rights. They also hold management rights for living organisms in the dam and its catchment. This authority makes them proprietors (able to determine access, withdrawal, management and exclusion rights) (refer to Table 1). In the absence of dedicated legislation for inland fisheries, the legal instruments that are being used by the provincial agencies of the environment are the 'provincial nature conservation legislations and ordinances' and also (post1994) the NEMA and the NEMBA.

\section{Use right practices}

Understanding the existing use right practices on public dams and other water bodies is important for future (re-)structuring of access rights, withdrawal rights and management rights, the relationship between access rights and management responsibilities for recreational, subsistence and commercial fishing, and more so if the communities are to have improved bundles of rights (Table 1) in order to derive increased benefits.

\section{Creation of ad hoc rights - recreational clubs and tourism concessions}

Recreational angling and other sports clubs currently and historically have had the dominant presence on public dams. Recreational fishing, sports clubs and tourist operators that had built facilities on public dam frontage and have been operating on dams, especially before 1994, exercise historical rights. This strong presence and historical use places these actors in a very strong position as 'existing lawful users' under the NWA. Legally, recreational clubs have access and withdrawal rights (Table 1) that enable them to enter the dam area, engage in recreational fishing (including tournaments) and also build infrastructure on the dam frontage for use by their members. In some instances, they fence off the areas (for example on Voëlvlei Dam) where they have developed facilities, thereby privatising such areas. Access to such areas is usually controlled through locked gates, with keys available to members or nonmembers who have been given permission to use club facilities. By controlling access to limit or deny use of their facilities, clubs de facto create exclusion rights well beyond the rights that the public dam regulations authorises them. The lease of land on the dam frontage to build lodges and guesthouses as part of tourism concessions legally gives such concessioners access rights only (and possibly withdrawal rights if they are using water from the dam for their guesthouse domestic purposes under Schedule 1). Clearly, proximity to dams enables them to create secondary rights such as access rights to the dam for water sports, cruises, etc., for their guests.

The position of recreational angling on dams has been further strengthened in the past by supportive provincial nature conservation legislation that largely caters for recreational angling and biodiversity conservation. Most provincial legislation does not facilitate or cater for subsistence and/or commercial fishing, de facto restricting or denying fishing rights for communities. In a country such as South Africa with a history of racially- and class-based exclusion practices from resources, surrounding communities have come to believe that they have no rights to access the dams, given that the public dams have predominantly been used for recreation and tourism. When recreational anglers and lodge owners try to limit or deny fishers from communities the right to fish, going to the extent of confiscating and destroying equipment such as happens on uPhongolo and Driekoppies Dams (Tapela et al., 2011), they are exercising exclusion rights that are not within the ambit of their rights as provided for by the authorisations that allow them usage of public dams. Of real concern is that the creation of exclusion rights by entrenched historical users has the potential for continued inequity in the allocation of subsistence and/or commercial fishing rights for communities. There will therefore be the need to revise existing policies and legislation so that these can provide for equitable and sustainable access to fish resources on dams. This would have to be addressed through reforms of access, withdrawal and management rights (Table 1) for inland fisheries through enabling policies and legislation. The lack of an inland fisheries policy has also meant that there has been a lack of appropriate institutional arrangements for subsistence and commercial fishing on dams.

\section{Subsistence and commercial fishing by communities}

Legally, communities (the term 'communities' is used here to refer largely to rural people under customary or traditional authority rule and also the formerly marginalised class of people in areas where customary rule does not exist, such as farm workers in the Western Cape) have access rights that the NWA gives to the general public from 6 am to $6 \mathrm{pm}$ (Barnes, 2011). In principle, they should also be able to fish using recreational permits, just like recreational anglers, in order to exercise withdrawal fishing rights. Poverty (the inability to buy such permits) or the lack of facilities at which to buy such permits 
(distance from the nearest Post Office or Inland Revenue Office, for example, for communities on Driekoppies dam), might act to force such communities to fish without permits, in effect fishing illegally or informally. Where people have historically fished without permits such as on Lake Fundudzi (local people hold communal rights through their chief; Tapela et al., 2011), the introduction of such measures could cause friction between fishing communities and regulatory authorities. This ambiguity in regulations and institutional arrangements is also the case on Nandoni and Makuleke Dams where local fishers do not use permits and frown upon being harassed about these, whether by conservation officials or their own chiefs (Tapela et al., 2011) If one is fishing for subsistence, then there is the clear dilemma whether permits are morally enforceable, even if a fisher might be catching volumes well beyond home use and is selling the extra catch (for example on Nandoni; Tapela et al., 2011). The main conflict arises though where fishers from communities use nets (for example in uPhongolo and Driekoppies Dams). In most provincial legislation (for example, the Provincial Government of Mpumalanga Nature Conservation Act (No. 10 of 1998) section 7.2.3, and the Provincial Government of Limpopo Environmental Management Act (No. 7 of 2003) section 7.2.5), the use of nets is banned, with angling being the only method of fishing legally allowed.

On uPhongolo Dam, the ongoing ambiguity of the legitimacy of fishing activities by communities has resulted in a fairly serious conflict between fishers from the communities on the east side of the dam, recreational fishing charter operators, and the KZN Ezemvelo Wildlife authorities. KZN Ezemvelo Wildlife has not issued permits for use of nets on the dam since 1998. Although the nets are being used illegally, the net fishers argue that they have authority from the Water User Association and/ or DWA to use nets. The DWA does not see why fishers from the community should be stopped from fishing while recreational fishers are allowed to fish (Nyawo, 2011). The DWA officials thus simply turn a blind eye to the fishing activities of net fishers from the community. KZN Ezemvelo Wildlife at the same time refrains from arresting and prosecuting net fishers due to the volatility of the situation. Meanwhile, some fishers from communities get their nets confiscated by anglers and/or guesthouse owners if they are caught fishing in the middle of the dam or on the western side of the dam where recreational and tourist activities pre-dominate. The underlying view (also enshrined in most provincial legislation) among most anglers and some environmental authorities is that nets are destructive, especially to the target species for angling and sports fishing, and should therefore be banned. It is in this context, therefore, that on some dams, such as uPhongolo and Driekoppies, anglers, lodge owners and recreational fishers take the law into their own hands and try to enforce the exclusion of gill nets on such dams.

\section{Co-management responsibilities}

Co-management is seen as the most appropriate governance arrangement for fisheries, especially those involving multiple stakeholders (Hara and Nielsen, 2003; Hauck and Sowman, 2001; McCay, 1993; Bromley, 1991; Ostrom, 1990; Jentoft, 1989; McCay and Acheson, 1987). South Africa's NWA provides for co-management structures to manage the use of public dams for various purposes. The NWA provides for the establishment of catchment management agencies (CMAs) in the country's 19 water management areas (these have now been consolidated to 9, as stated in the National Water Resource Strategy 2; DWA, 2013). CMAs are supposed to be vehicles for devolution of management authority and responsibility. The Act requires that each CMA draws up a management strategy for their catchment, which includes the active promotion of user participation including communities (section 80 (e)). This has been given further substance by NWA implementation guidelines published by DWAF (2001) which emphasize that representivity and inclusivity of all stakeholders' interests, needs and values, especially those of hitherto marginalised communities and the rural poor, will need to be considered as part of the catchment management process. A second management body proposed by the NWA is water user associations (WUAs), which are statutory bodies defined as cooperative institutions for individual water users who wish to undertake water-related activities for their mutual benefit. The involvement of users in management through CMAs and/or WUAs offers to create and extend management rights to users. WUAs have to date not been effectively used to manage fishing rights and it is questionable whether such bodies can be used for strengthening and protecting fishing property and access rights for communities without significant government intervention and support. The problem is that such bodies usually involve power dynamics, resulting in capture of power and authority by the most economically powerful for their own interests. There is already a concern that most WUAs and CMAs are dominated by organised interests such as commercial farmers, through their irrigation boards that are members of such bodies (Sithole, 2011). Included in the NWA as a way to incorporate farmer associations and irrigation boards, WUAs present formidable challenges as vehicles for inclusion of communities in water and fisheries management. The Pongola Dam Recreational WUA illustrates this point, as this organisation has been ineffective in addressing the fishery conflicts on the dam. One can envisage inland fisheries management organisations being equally dominated by established angling clubs and interests. In effect, the poorly educated and resourced fishers from communities are likely to be vulnerable to marginalisation in such groupings unless there are specific facilitated interventions to promote their fair and equal participation.

If the aim is to strengthen the participatory management rights of rural community fishers, the creation of co-governance bodies that will provide an empowering space for management rights for communities is required. This will require the granting of access, withdrawal and management rights to co-management bodies on behalf of the members. Granting such rights to community user group organisations will require reforms to existing policy and legislation. The co-management bodies could then control the activities of their stakeholders by granting the group's rights to the individual members. In order for communities to participate as equal partners, they will have to be empowered through training and awareness-raising about their rights, principles of sustainable use and the regulatory frameworks under which inland fisheries will be managed.

\section{Need for a developmental approach}

Provincial legislation might not provide for a complete shift away from the current conservative conservation-oriented management style towards a developmentalist 'sustainable utilisation' approach that is necessary for the promotion and exploitation of inland fisheries). The Constitution, NEMA and NEMBA have adequate provisions for such a developmental and livelihoods approach to the utilisation of inland fisheries. If government policy is oriented towards obtaining maximum and equitable socio-economic benefit from utilisation of 
fishery resources in dams, future interventions would call for a developmental approach to inland fisheries. Such an approach will ideally require the leadership of DAFF, the line agency for the development and management of fisheries. DAFF has developed a 20-year (2011 to 2031) Integrated Growth and Development Plan (IG\&DP) (DAFF, 2010), which provides a long-term strategic plan for growth and development of the three sectors (agriculture, forestry and fisheries) in line with Government priorities. Of note is that the new Policy for the Small Scale Fisheries Sector in South Africa (RSA, 2012) is for marine fisheries only. Thus, currently, there is no legislation legally recognising the existence of inland capture fisheries.

In reference to the proposed governance and institutional framework (Fig. 1), the following can be stipulated: Although it might be impossible to use one blanket legislation for all water bodies due to the varying biological and ecological characteristics of water bodies (Weyl, 2012) and the geographical areas in which they occur, type and number of stakeholders and use types for each water body, there is a need for common principles, as provided for by NEMA, NWA, the Constitution and DAFF's strategic plan. These should guide the development and management of inland fisheries and also the legal instruments that underpin these. These principles should be founded upon a developmental approach, equitable distribution, sustainable use, and inclusive/cooperative governance and knowledge base for inland fisheries. The current provincial legislation that is being used does not reflect the livelihoods dimensions of nature and fisheries utilisation. Key to any future revisions of legislation and the principles thereof would therefore be to align these with the National Development Plan (National Planning Commission, 2011) and other Government developmental policies and strategies, especially those regarding a development approach to natural resource management based on encouragement and enhancement of sustainable rural livelihoods. A review of human capacity (both in terms of numbers and skills) and infrastructure for the development of inland fisheries will need to be part of such a strategic plan.

\section{CONCLUSIONS}

With over 700 public storage dams and communal-based water bodies that represent over $50 \%$ of the total inland water surface, South Africa has great potential and opportunity for the development and enhancement of a livelihoods-based inland fishery. Such a sector could be an important source of protein especially for food-insecure rural communities. In addition, the dams also provide opportunities for inclusion of communities in the recreational angling and tourism value chains, where such activities occur.

In principle, the custodial departments, especially DWA, have public ownership rights on behalf of South African citizens. Water bodies in communal areas fall under traditional authorities who exercise ownership rights on behalf of their subjects. Some dams exist under more than one property rights regime. For example, although Nandoni and Makuleke Dams legally belong to the DWA, the lack of presence by the provincial environmental agencies means that the local chiefs are de facto exercising proprietary rights, especially for fishing. In this context such dams exist under dual property rights regimes - both public and communal. Consensus on the appropriate management regime(s) among all stakeholders for each water body will be key for equitable sustainable utilisation.

On most dams, recreational fishing has become a well entrenched activity through existing historical use rights.
Unlike recreational fishing, subsistence fishing rights are poorly defined or not even recognised within the existing legislation. The ambiguity of the legal status of subsistence fishing generates conflicts with recreational fishers and other users on such dams. The challenge is to accommodate those fishing for a livelihood alongside the legally entrenched users in a manner that is equitable and sustainable for all users.

The management of biodiversity on dams resides with the provincial environmental agencies through use of provincial Nature Conservation Acts and ordinances. The promulgation of the 1996 Constitution, NEMA and NEMBA, has meant that there is need to revise the provincial legislation and ordinances in line with these laws. The conservation-oriented approach and lack of a developmental approach to management of biodiversity by provincial environmental agencies means that there is even more pressure for reform.

The NWA requires formation of CMAs and WUAs. Both these organisations are based on principles of user participation and inclusive governance. The real question is whether these bodies could be used for inland fisheries co-management and in so doing strengthen the rights of rural communities to fisheries on public dams. Experience so far has been that most of these bodies have mainly included the already well established and well organised stakeholder groups such as irrigation farmers and recreational anglers, with communities poorly represented or not at all. A key future role for the responsible agency for inland fisheries will therefore be to create institutional arrangements and governance structures that can ensure that communities are adequately and meaningfully represented on such fora. Where dams are under communal tenure, as with Lake Fundudzi, it might be more prudent going forward to take an approach that strengthens the existing community-based management and governance arrangements.

If Government policy is towards maximisation of socioeconomic benefits from utilisation of dams for fisheries by communities, interventions for governing inland fisheries will need to be based on a developmental approach. This would require revision of policy and legislation in line with such an approach and with the leadership of DAFF.

\section{ACKNOWLEDGEMENTS}

This paper is based on research under the project titled 'Baseline and scoping study on the development and sustainable utilisation of storage dams for inland fisheries and their contribution to rural livelihoods' (Project No. K5/1957), initiated and funded by the Water Research Commission, with the collaboration of the Department of Agriculture, Forestry and Fisheries. The contents of the article are the authors sole responsibility and should not be regarded as reflecting the views and position of the WRC or DAFF. We would like to thank all the interviewees that availed themselves for this research. Without the WRC's funding and the cooperation of all of the interviewees, this research would not have been possible.

\section{REFERENCES}

ALCHIAN A and DEMSETZ H (1973) The property rights paradigm. J. Econ. Hist. 33 (1) 16-27.

BACKEBERG GR (2012) Inland freshwater fisheries: Conceptual framework. Proceedings of the Inland Fisheries Consultative Workshop for Government Stakeholders, 7 March 2012, Water Research Commission, Pretoria. 
BACKEBERG GR (2010) Improving rural livelihoods with rainwater harvesting and conservation on communal croplands in South Africa: Opportunities and obstacles. In: Behl RK, Merbach W, Meliczek H and Kaetsch C (eds.) Crop Science and Land Use for Food and Bioenergy. AGROBIOS (International), Jodpur, India. 299-317.

BARNES J (2011) Personal communication, 4 August 2011. Mr Jonathan Barnes, (Department of Water Affairs) Water Control Officer for Western Cape (Areas 17\& 19), Voëlvlei.

BÉNÉ CB, HERSOUG B and ALLISON EH (2010) Not by rent alone: Analysing the pro-poor functions of small-scale fisheries in developing countries. Dev. Polic. Rev. 28 (3) 325-358.

BÉNÉ C, MACFADYEN G and ALLISON EH (2007) Increasing the Contribution of Small-Scale Fisheries to Poverty Alleviation and Food Security. FAO Fisheries Technical Paper. No. 481. Food and Agriculture Organization, Rome.

BERKES F (ed) (1989) Common Property Resources: Ecology and Community-Based Sustainable Development. Belhaven Press, London.

BROMLEY DW (1991) Environment and Economy: Property Rights and Public Policy. Blackwell, Oxford

BROMLEY D (1989) Property Relations and economic development: The other land reform. World Dev. 17 (6) 876-877.

BROMLEY DW and CERNEA MM (1989) The Management of Common Property Resources: Some Conceptual and Operational Fallacies. World Bank Discussion Paper 57. World Bank. Washington, DC.

CIRIACY-WANTRUP SV and BISHOP RC (1975) "Common property" as a concept in natural resource policy. Nat. Resour. J. 15 (4) $713-727$.

DAFF (DEPARTMENT OF AGRICULTURE, FORESTRY AND FISHERIES, SOUTH AFRICA) (2010) Integrated Growth and Development Plan 2011-2031. Department of Agriculture, Forestry and Fisheries, Pretoria.

DWA (DEPARTMENT OF WATER AFFAIRS, SOUTH AFRICA) (2013) National Water Resource Strategy 2. Department of Water Affairs, Pretoria.

DWA (DEPARTMENT OF WATER AFFAIRS, SOUTH AFRICA) (2010) List of Registered Dams 2010. URL: http://www.dwa.gov.za/ DSO/Publications.aspx (Accessed 15 June 2012).

DWAF (DEPARTMENT OF WATER AFFAIRS AND FORESTRY, SOUTH AFRICA) (1997) White Paper on a National Water Policy for South Africa. DWAF, Pretoria. URL: http://www.dwaf.gov.za/ Documents/Policies/nwpwp.pdf.

FAO (2009) Report of the Global Conference on Small-Scale Fisheries "Securing Sustainable Small-Scale Fisheries: Bringing Together Responsible Fisheries and Social Development” 13-17 October 2008, Bangkok. Food and Agriculture Organization, Rome.

FAO (2005) Fish for All Summit, 22-25 August 2005, Lagos. URL: http://www.fishforall.org/ffa-summit/africasummit.asp (Accessed 23 April 2013).

FAO (2003) Strategies for Increasing the Sustainable Contribution of Small-scale Fisheries to Food Security and Poverty Alleviation. Committee on Fisheries, $25^{\text {th }}$ Session. Food and Agriculture Organization, Rome.

HARA M and NGWEXANA B (2011) Recommendations for Revisions to Inland Fishery Property Rights Regimes and Access Rights. Deliverable 10 for WRC Project No. K5/1957 (tabled at Reference Group meeting on 12 April 2011, Rhodes University): Baseline and scoping study on the development and sustainable utilisation of storage dams for inland fisheries and their contribution to rural livelihoods. KSA: Water Utilisation in Agriculture, Water Research Commission, Pretoria.

HARA M and NIELSEN JR (2003) Experiences with fisheries comanagement in Africa. In: Wilson DC, Nielsen JR and Degnbol P (eds.) The Fisheries Co-management Experience: Accomplishments, Challenges and Prospects. Kluwer Academic Publishers. Dordrecht. 81-95.

HAUCK M and SOWMAN M (2001) Coastal and fisheries co-management in South Africa: An overview and analysis. Mar. Polic. 25 (2001) 173-185
HECK S, BÉNÉ C and REYES-GASKIN R (2007) Investing in African fisheries: Building links to the Millennium Development Goals. Fish Fish. 8 (3) 211-226.

JENTOFT S and EIDE A (eds.) (2011) Poverty Mosaics: Realities and Prospects in Small-scale Fisheries. Springer, Amsterdam.

JENTOFT S (1989) Fisheries co-management: Delegating government responsibility to fishermen's organisations. Mar. polic. (April 1989) $137-154$.

MANONA S and BAIPHETHI M (2008) Developing a Land Register and a Set of Rules for Application of Infield Rainwater Harvesting in Three Villages in Thaba Nchu: A Pilot Project. WRC Report No. TT 367/08. Water Research Commission, Pretoria.

McCAFFERTY JR, ELLENDER BR, WEYL O and BRITZ PJ (2012) The use of water resources for inland fisheries in South Africa. Water SA 38 (2) 327-343.

McCAY BJ (1993) Common and Private concerns. Paper presented at: Nordic Symposium on Anthropology and Nature, 28-30 October 1993, Thorshavn.

McCAY BJ and ACHESON JM (eds.) (1987) The Question of the Commons: The Culture of Ecology of Communal Resources. The University of Arizona Press, Tucson.

McKEAN MA (1992) Success on the commons: a comparative examination of institutions for common property resource management. J. Theor. Polit. 4 (3) 247-281.

NATIONAL PLANNING COMMISSION (2011) National Development Plan: Vision 2030. South African National Planning Commission, Pretoria.

NETTING R (1981) Balancing on an Alp: Ecological Change and Continuity in a Swiss Mountain Community. Cambridge University Press, New York.

NYAWO M (2011) Personal communication, 10 August 2011. Mr Mazwi Njawo, Senior Water Control Officer (Department of Water Affairs), Pongola Dam.

OSTROM E (2008) Design principles of robust property-rights institutions: What have we learned? Paper presented at: Land Policies and Property Rights, 2-3 June 2008, Lincoln Institute of Land Policy, Cambridge, MA.

OSTROM E (1990) Governing the Commons: The Evolution of Institutions for Collective Action. Cambridge University Press, Cambridge.

OSTROM E (1986) Issues of definition and theory: Some conclusions and hypotheses. Proceedings of the Conference on Common Property Resources Management. National Academy Press, Washington, DC. 599-615.

PROVINCIAL GOVERNMENT OF LIMPOPO (2003) Limpopo Environmental Management Act No. 7 of 2003. Provincial Government of Limpopo, Polokwane.

PROVINCIAL GOVERNMENT OF MPUMALANGA (1998) Mpumalanga Nature Conservation Act No. 10 of 1998. Provincial Government of Mpumalanga, Nelspruit.

RSA (REPUBLIC OF SOUTH AFRICA) (2012) Policy for the Small Scale Fisheries Sector in South Africa. Government Gazette 35455. Government Printer, Pretoria.

RSA (REPUBLIC OF SOUTH AFRICA) (2004) National Environmental Management: Biodiversity Act (Act 10 of 2004). Government Printer, Pretoria.

RSA (REPUBLIC OF SOUTH AFRICA) (2004) Communal Land Rights Act (Act 11 of 2004). Government Printer, Pretoria.

RSA (REPUBLIC OF SOUTH AFRICA) (2003) Traditional Leadership and Governance Framework (TLGF) Amendment Act (Act 41 of 2003). Government Printer, Pretoria.

RSA (REPUBLIC OF SOUTH AFRICA) (1998) National Environmental Management Act (Act 107 of 1998). Government Printer, Pretoria.

RSA (REPUBLIC OF SOUTH AFRICA) (1998) National Water Act (Act 36 of 1998). Government Printer, Pretoria.

RSA (REPUBLIC OF SOUTH AFRICA) (1997) Water Services Act (Act 108 of 1997). Government Printer, Pretoria.

RSA (REPUBLIC OF SOUTH AFRICA) (1996) Constitution of the Republic of South Africa (Act 108 of 1996). Government Printer, Pretoria. 
SCHLAGER E (1994) Fishers' institutional responses to common-pool resource dilemmas. In: Ostrom E, Gardner R and Walker J (eds.) Rules, Games and Common-Pool Resources. University of Michigan Press, Ann Arbor. 247-266.

SCHLAGER E and OSTROM E (1992) Property-rights regimes and natural resources: A conceptual analysis. Land Econ. 68 (3) 249-262.

SITHOLE P (2011) A Comparative Study of Rural Water Governance In the Limpopo Basin. PhD thesis, University of the Western Cape.

TANG SY (1994) Institutions and Performance in Irrigation Systems. In: Ostrom E, Gardner R and Walker J (eds.) Rules, Games and Common-Pool Resources. University of Michigan Press, Ann Arbor. 225-246.

TAPELA BN, JENJEZWA VR, MAGOBA RM and HLONGWANI AG (2011) Research report to characterise indigenous knowledge and practice and current subsistence, commercial and recreational techniques and practices for using fish in storage dams in selected rural areas of South Africa'. Deliverable 12 Report 4 for WRC Project No. K5/1957 (tabled at Reference Group Meeting on 12 April 2011, Rhodes University): Baseline and scoping study on the development and sustainable utilisation of storage dams for inland fisheries and their contribution to rural livelihoods. Africa Centre for Water Research (ACWR). Cape Town. KSA: Water Utilisation in Agriulture, Water Research Commission, Pretoria.

WATER RESEARCH COMMISSION (2011) Abridged Knowledge Review 2010/11. Water Research Commission, Pretoria.

WEYL O (2012) GIS Mapping and Bibliography of Dams with Inland Fisheries Potential. Deliverable 17 for WRC Project No. K5/1957 (tabled at Reference Group meeting on 11 April 2012, PLAAS, University of the Western Cape: Baseline and scoping study on the development and sustainable utilisation of storage dams for inland fisheries and their contribution to rural livelihoods. KSA: Water Utilisation in Agriculture, Water Research Commission, Pretoria. WEYL O, POTTS W, ROUHANI Q and BRITZ P (2007) The need for inland fisheries policy in South Africa: A case study of the North West Province. Water SA 33 (4) 497-504.

WORLD BANK (2004) Saving Fish and Fishers. World Bank, Washington, DC.

YOUNG OR (1989) International Cooperation: Building Regimes for Natural Resources and the Environment. Cornell University Press.

APPENDIX

\begin{tabular}{|c|c|c|c|c|c|c|c|c|c|}
\hline \multicolumn{10}{|c|}{$\begin{array}{l}\text { TABLE A1 } \\
\text { Property rights, access rights and management arrangements on the sampled dams (from: Hara and Ngwexana, 2011) }\end{array}$} \\
\hline \multirow[t]{2}{*}{ Variable } & \multicolumn{3}{|l|}{ Western Cape } & \multicolumn{3}{|l|}{ Limpopo } & \multirow{2}{*}{\begin{tabular}{|l|l} 
Mpumalanga \\
Driekoppies
\end{tabular}} & KZN & \multirow{2}{*}{\begin{tabular}{|l|} 
Free State \\
Bloemhof
\end{tabular}} \\
\hline & Voëlvlei & Clanwilliam & \begin{tabular}{l|}
$\begin{array}{l}\text { Theewaters- } \\
\text { kloof }\end{array}$ \\
\end{tabular} & Nandoni & Makuleke & \begin{tabular}{|l} 
Lake \\
Fundudzi
\end{tabular} & & uPhongolo & \\
\hline \multicolumn{10}{|c|}{ Type of resource } \\
\hline - $\quad$ Storage dam & $\mathrm{Y}$ & $\mathrm{Y}$ & $\mathrm{Y}$ & $\mathrm{Y}$ & $\mathrm{Y}$ & & $\mathrm{Y}$ & $\mathrm{Y}$ & $\mathrm{Y}$ \\
\hline - Lake & & & & & & $\mathrm{Y}$ & & & \\
\hline \multicolumn{10}{|l|}{ - $\quad$ River } \\
\hline Legal custodian & DWA & DWA & DWA & DWA & DWA & $\begin{array}{l}\text { Local } \\
\text { community }\end{array}$ & KOBWA $^{1}$ & DWA & DWA \\
\hline \multicolumn{10}{|c|}{ Property rights regime } \\
\hline $\begin{array}{ll}\text { - } & \text { Public (name } \\
\text { of legal } \\
\text { custodian) }\end{array}$ & Y & Y & $\mathrm{Y}$ & $\mathrm{Y}$ & y & & $\begin{array}{l}\text { Y (Govts. } \\
\text { of South } \\
\text { Africa and } \\
\text { Swaziland) } \\
\end{array}$ & $\mathrm{y}$ & Y \\
\hline - Communal & & & & $\mathrm{Y}$ & $\mathrm{Y}$ & $\mathrm{Y}$ & & & \\
\hline $\begin{array}{l}\text { Non- } \\
\text { property } \\
\text { (open) }\end{array}$ & & & & & & & & & \\
\hline \multirow[t]{5}{*}{$\begin{array}{l}\text { Who are the } \\
\text { agents (users)? }\end{array}$} & DWA & DWA & DWA & DWA & Irrigation & $\begin{array}{l}\text { Local } \\
\text { communities }\end{array}$ & KOBWA $^{1}$ & DWA & $\begin{array}{l}\text { Farmers } \\
\text { downstream }\end{array}$ \\
\hline & $\begin{array}{l}\text { City of Cape } \\
\text { Town }\end{array}$ & $\begin{array}{l}\text { Cederberg } \\
\text { Municipality }\end{array}$ & \begin{tabular}{|l|} 
City of Cape \\
Town, Paarl, \\
Wellington \\
\end{tabular} & Communities & Community & & DWA & $\begin{array}{l}\text { EKZN } \\
\text { Wildlife }\end{array}$ & $\begin{array}{l}\text { Commer- } \\
\text { cial fishing } \\
\text { operators } \\
\end{array}$ \\
\hline & $\begin{array}{l}\text { Swartland } \\
\text { Municipality }\end{array}$ & $\begin{array}{l}\text { Clanwilliam } \\
\text { Water } \\
\text { Users Assoc } \\
\text { (includes } \\
\text { farmers) }\end{array}$ & Yatch Club & Boating club & Farmers & & $\begin{array}{l}\text { Komati } \\
\text { Irrigation } \\
\text { Schemes }\end{array}$ & $\begin{array}{l}\text { Nyawo } \\
\text { community }\end{array}$ & Boat clubs \\
\hline & $\begin{array}{l}\text { Irrigation } \\
\text { Farmers }\end{array}$ & $\begin{array}{l}\text { Lower } \\
\text { Olifants } \\
\text { River Water } \\
\text { Users Assoc } \\
\text { (includes } \\
\text { farmers) } \\
\end{array}$ & \begin{tabular}{|l|} 
Overberg \\
Municipality
\end{tabular} & $\begin{array}{l}\text { Campers } \\
\text { (caravan } \\
\text { parks) } \\
\text {-informal }\end{array}$ & & & $\begin{array}{l}\text { Irrigation } \\
\text { farmers }\end{array}$ & $\begin{array}{l}\text { Private land- } \\
\text { owners (with } \\
\text { frontage and } \\
\text { use) }\end{array}$ & $\begin{array}{l}\text { Irrigation } \\
\text { farmers } \\
\text { downstream }\end{array}$ \\
\hline & $\begin{array}{l}\text { Angling } \\
\text { clubs }\end{array}$ & Anglers & $\begin{array}{l}\text { Private hous- } \\
\text { ing develop- } \\
\text { ments on } \\
\text { the upper } \\
\text { catchment }\end{array}$ & $\begin{array}{l}\text { Picnics (one } \\
\text { site run by } \\
\text { local chief) }\end{array}$ & & & $\begin{array}{l}\text { Angling } \\
\text { clubs }\end{array}$ & $\begin{array}{l}\text { Swaziland } \\
\text { Govt }\end{array}$ & $\begin{array}{l}\text { Recreational } \\
\text { anglers }\end{array}$ \\
\hline
\end{tabular}




\begin{tabular}{|c|c|c|c|c|c|c|c|c|c|}
\hline \multirow[t]{5}{*}{ Ithaca, New Yo } & $\begin{array}{l}\text { lechting } \\
\text { club }\end{array}$ & $\begin{array}{l}\text { Yachting } \\
\text { Club }\end{array}$ & $\begin{array}{l}\text { Irrigation } \\
\text { farmers } \\
\text { (Rivier- } \\
\text { sonderend, } \\
\text { Upperberg, } \\
\text { Eerste and } \\
\text { Wynland } \\
\text { Irrigation } \\
\text { Boards) } \\
\end{array}$ & & & & $\begin{array}{l}\text { Local } \\
\text { communities }\end{array}$ & $\begin{array}{l}\text { Private } \\
\text { tourism } \\
\text { concession } \\
\text { (access and } \\
\text { use only) }\end{array}$ & $\begin{array}{l}\text { Subsistence } \\
\text { anglers from } \\
\text { Bloemhof }\end{array}$ \\
\hline & Guest House & Guesthouses & Guesthouses & & & & $\begin{array}{l}\text { General } \\
\text { public }\end{array}$ & & $\begin{array}{l}\text { General } \\
\text { public }\end{array}$ \\
\hline & \begin{tabular}{|l} 
Farm \\
workers
\end{tabular} & Water sports & Campers & & & & \begin{tabular}{|l|} 
Mozambique \\
$($ downstream)
\end{tabular} & & \begin{tabular}{|l}
$\begin{array}{l}\text { Nature } \\
\text { reserves }\end{array}$ \\
\end{tabular} \\
\hline & $\begin{array}{l}\text { General } \\
\text { public }\end{array}$ & & Water sports & & & & & & \\
\hline & $\begin{array}{l}\text { Environment } \\
\text { (Reserve) }\end{array}$ & $\begin{array}{l}\text { Environment } \\
\text { (Reserve) }\end{array}$ & $\begin{array}{l}\text { Environment } \\
\text { (Reserve) }\end{array}$ & \begin{tabular}{|l|}
$\begin{array}{l}\text { Environment } \\
\text { (Reserve) }\end{array}$ \\
\end{tabular} & \begin{tabular}{|l|} 
Environment \\
(Reserve)
\end{tabular} & & \begin{tabular}{|l|} 
Environment \\
(Reserve)
\end{tabular} & \begin{tabular}{|l|}
$\begin{array}{l}\text { Environment } \\
\text { (Reserve) }\end{array}$ \\
\end{tabular} & $\begin{array}{l}\text { Environment } \\
\text { (Reserve) }\end{array}$ \\
\hline \multicolumn{10}{|l|}{ Management } \\
\hline $\begin{array}{l}\text { Who is } \\
\text { respon- } \\
\text { sible for } \\
\text { management }\end{array}$ & $\begin{array}{l}\text { DWA, Cape } \\
\text { Nature, } \\
\text { Dam } \\
\text { Committee } \\
\end{array}$ & $\begin{array}{l}\text { DWA, Cape } \\
\text { Nature }\end{array}$ & $\begin{array}{l}\text { DWA, } \\
\text { Cape Nature }\end{array}$ & $\begin{array}{l}\text { DWA, local } \\
\text { chiefs }\end{array}$ & $\begin{array}{l}\text { DWA, local } \\
\text { chiefs }\end{array}$ & $\begin{array}{l}\text { Traditional } \\
\text { authorities }\end{array}$ & $\begin{array}{l}\text { DWA, } \\
\text { KOBWA }^{1}\end{array}$ & $\begin{array}{l}\text { DWA, } \\
\text { Ezemvelo } \\
\text { KZN } \\
\text { Wildlife } \\
\end{array}$ & $\begin{array}{l}\text { DWA, FS } \\
\text { EDTEA }^{2}\end{array}$ \\
\hline $\begin{array}{l}\text { - } \begin{array}{l}\text { Source of } \\
\text { stewardship } \\
\text { power }\end{array} \\
\end{array}$ & $\begin{array}{l}\text { NWA, } \\
\text { provincial } \\
\text { legislation, } \\
\text { NEMA, } \\
\text { NEMBA }\end{array}$ & $\begin{array}{l}\text { NWA, } \\
\text { provincial } \\
\text { legislation, } \\
\text { NEMA, } \\
\text { NEMBA }\end{array}$ & $\begin{array}{l}\text { NWA, } \\
\text { provincial } \\
\text { legislation, } \\
\text { NEMA, } \\
\text { NEMBA }\end{array}$ & $\begin{array}{l}\text { NWA, local } \\
\text { Informal } \\
\text { traditional } \\
\text { authority }\end{array}$ & $\begin{array}{l}\text { NWA, local } \\
\text { informal } \\
\text { traditional } \\
\text { authority }\end{array}$ & $\begin{array}{l}\text { Local } \\
\text { informal } \\
\text { traditional } \\
\text { authority }\end{array}$ & $\begin{array}{l}\text { NWA, } \\
\text { provincial } \\
\text { legislation, } \\
\text { NEMA, } \\
\text { NEMBA, } \\
\text { KOBWA }{ }^{1} \\
\text { pact }\end{array}$ & $\begin{array}{l}\text { NWA, } \\
\text { provincial } \\
\text { legislation, } \\
\text { NEMA, } \\
\text { NEMBA }\end{array}$ & $\begin{array}{l}\text { NWA, } \\
\text { provincial } \\
\text { legislation, } \\
\text { NEMA, } \\
\text { NEMBA }\end{array}$ \\
\hline \multicolumn{10}{|c|}{ Management arrangements } \\
\hline - Centralised & $\begin{array}{l}\text { DWA, Cape } \\
\text { Nature }\end{array}$ & $\begin{array}{l}\text { DWA, Cape } \\
\text { Nature }\end{array}$ & Y & $\mathrm{Y}$ & $\mathrm{Y}$ & & KOBWA $^{1}$ & \begin{tabular}{|l|} 
Y (DWA, \\
Ezemvelo \\
KZN \\
Wildlife) \\
\end{tabular} & $\begin{array}{l}\text { Y (DWA, FS } \\
\left.\text { EDTEA }^{2}\right)\end{array}$ \\
\hline Communal & & & & $\mathrm{Y}$ & $\mathrm{Y}$ & $\mathrm{Y}$ & & & \\
\hline $\begin{array}{l}\text { Co-manage- } \\
\text { ment } \\
\text { committee }\end{array}$ & $\begin{array}{l}\text { There is } \\
\text { a Dam } \\
\text { Committee }\end{array}$ & WUAs & $\begin{array}{l}\text { Cape Nature } \\
\text { works with } \\
\text { Yacht Club }\end{array}$ & & $\begin{array}{l}\text { DWA, } \\
\text { WUAs and } \\
\text { Municipality } \\
\text { working } \\
\text { together }\end{array}$ & & \begin{tabular}{|l|} 
Irrigation \\
boards, \\
DWA,WUAs, \\
Municipality
\end{tabular} & $\begin{array}{l}\text { uPhongolo } \\
\text { WUAs }\end{array}$ & \\
\hline
\end{tabular}

${ }^{1}$ KOBWA: Komati Basin Water Authority

${ }^{2}$ FS EDTEA: Free State Department of Economic Development, Tourism and Environmental Affairs 